\title{
Éditorial
}

\section{COMBUSTION EN BOUCLE CHIMIQUE (CLC)}

Le concept de combustion en boucle chimique (CLC; Chemical Looping Combustion) est apparu récemment comme une nouvelle voie prometteuse vouée à fournir des solutions propres et efficaces pour plusieurs applications telles que la combustion d'hydrocarbures et la production de gaz de synthèse/d'hydrogène. Le concept de la boucle chimique repose simplement sur l'utilisation de matériaux porteurs d'oxygène dans des cycles d'oxydation-réduction pour oxyder ou réduire des réactifs. Ainsi, une combustion peut être obtenue sans contact direct entre l'air et le combustible, et des effluents riches en $\mathrm{CO}_{2}$ peuvent être produits directement, permettant ultérieurement le transport et le stockage du $\mathrm{CO}_{2}$. Aucune séparation spécifique de l'oxygène dans l'air ou du $\mathrm{CO}_{2}$ dans les fumées de combustion n'est requise, ce qui conduit potentiellement à de bien plus faibles pénalisations énergétiques. De ce fait, la CLC est considérée comme une technologie potentiellement en rupture pour répondre aux défis de captage et de stockage du $\mathrm{CO}_{2}$. Le concept de CLC, en réalité, est apparu dans les années quatre-vingt-dix, à partir des travaux novateurs du Professeur Ishida au Japon. Depuis, au cours de la dernière décennie, un grand nombre de travaux ont été consacrés à la validation du concept et à l'évaluation d'applications industrielles potentielles telles que la combustion d'hydrocarbures. Un nombre croissant de programmes de recherches est consacré à la CLC partout dans le monde, parrainé par des gouvernements, des institutions publiques et des industriels, et l'Europe est à la tête de ces efforts. De nos jours, la CLC n'est plus un rêve, elle représente maintenant un concept bien établi, grâce à un bon nombre d'installations pilote opérant à petite échelle. La prochaine décennie sera la période de développement du procédé, au cours de laquelle il faudra transformer le concept bien établi en une solution industrielle viable. Étape par étape, un grand nombre de défis subsistants en termes de matériaux, de procédé et de technologie sera résolu afin d'aborder la perspective du captage et stockage de $\mathrm{CO}_{2}$ avec une solution nouvelle, propre et efficace.

IFP Energies nouvelles est engagé dans la CLC depuis longtemps par le biais de programmes français et européens, et travaille actuellement activement au développement de la technologie conjointement avec Total. Lorsque nous nous sommes rendus dans les universités les plus en pointe dans le domaine en Europe, à Chalmers, à Saragosse et à Vienne, il y a trois ans, nous avons pris conscience, avec les Professeurs Lyngfelt, Adanez et Hofbauer, de la nécessité de rassembler la communauté de CLC naissante afin d'échanger sur les progrès de la recherche, les applications potentielles ainsi que sur les besoins et défis de R\&D. Nous avons ainsi proposé d'accueillir la $1^{r e}$ Conférence Internationale sur la CLC dans le cadre des «Rencontres Scientifiques d'IFP Energies nouvelles ». En effet, ces Rencontres possèdent la capacité tout à fait reconnue de réunir les acteurs du monde de la recherche universitaire, de la recherche appliquée et de l'industrie sur des sujets prometteurs naissants telle que la CLC.

La Conférence s'est tenue du 17 au 19 mars 2010 dans les locaux d'IFP Energies nouvelles à Lyon, France, sous le parrainage de Total, Alstom, Vattenfall et CPFD Software. Elle a réuni environ 155 représentants du monde entier dont environ $50 \%$ d'institutions de recherche et d'organisations industrielles, pour débattre :

- sur les matériaux utilisables dans la boucle chimique : développement de matériaux synthétiques, réactivité, capacités de transfert d'oxygène, durée de vie et désactivation des matériaux, attrition, etc. 
- sur la technologie et sur la modélisation des réacteurs de la boucle chimique : développement de réacteurs, transport des particules porteurs d'oxygène, moyens de test, nature des charges gaz, liquides ou solides, modélisation des réactions et modélisation du procédé, etc.

- sur les applications de la boucle chimique et sur la problématique de l'extrapolation : applications potentielles, extrapolation, études de faisabilité et évaluations technicoéconomiques, etc.

Pendant 3 jours, 4 conférences plénières, 33 présentations orales et 30 posters ont été présentés et peuvent être téléchargés à partir du site Internet IFP Energies nouvelles à l'adresse :

http://www.ifpenergiesnouvelles.fr/actualites/evenements/congres-et-conferences/organises-parifp-energies-nouvelles/rs-chemical-looping

Ce numéro spécial sur la CLC de «Oil \& Gas Science and Technology» contient 14 publications scientifiques écrites à partir de certaines des communications présentées au cours de la Conférence. Dans leur ensemble, ces articles permettent de faire une revue complète de l'état actuel de la recherche en CLC et présentent un certain nombre des questions clefs pour le développement futur de la CLC qui ont été débattues au cours de la Conférence, telles que l'utilisation et les performances de matériaux synthétiques et de minerais naturels, les mécanismes d'oxydation-réduction des matériaux, la stabilité mécanique et l'attrition, les mécanismes réactionnels de combustion en fonction de la nature des charges et des matériaux, le dimensionnement des installations pilotes, la circulation de matériaux, la modélisation de réacteurs et l'utilisation de la CFD pour les applications de la CLC.

Au cours de la Table Ronde concluant la Conférence, il a été clairement affirmé que le futur de la CLC dépendra de notre capacité à gérer et optimiser les matériaux, les processus et les technologies à des échelles de plus en plus grandes, afin de rendre la technologie de CLC accessible à l'industrie énergétique dès que possible, dans un délai de 10 à 20 ans. Afin d'y parvenir, un grand nombre de recherches restent à mener dans le domaine des matériaux et de la maîtrise des réactions, mais aussi en matière d'optimisation dans la conception des réacteurs et dans la modélisation du procédé afin de minimiser les incertitudes lors de l'extrapolation. Un grand nombre d'interactions seront donc requises entre les chercheurs de différents domaines mais également entre les chercheurs, les institutions et les industriels. Il y donc un besoin fort de réunions ouvertes et régulières consacrées à la CLC. La première conférence, qui s'est tenue à Lyon, a constitué une première étape réussie et il a donc été décidé d'organiser une deuxième conférence dans les 2 ans. Cette $2^{\mathrm{e}}$ Conférence internationale sur la CLC sera accueillie par l'Université de Darmstadt en Allemagne et sera organisée par le Professeur J. Strohle. Cela nous donnera l'opportunité de suivre les évolutions rapides dans le domaine de la boucle chimique.

Thierry Gauthier

Correspondant scientifique de la Conférence CLC

Expert IFP Energies nouvelles 


\section{Editorial}

\section{CHEMICAL LOOPING COMBUSTION (CLC)}

The concept of Chemical Looping Combustion (CLC) has recently emerged as a promising new pathway to provide clean and efficient solutions for several applications including hydrocarbon combustion and syngas/hydrogen production. Chemical looping is based simply on the use of oxygen carrier materials in oxidation-reduction cycles to oxidize or reduce the reactants. Combustion can therefore take place with no direct contact between air and fuel, and $\mathrm{CO}_{2}$ rich effluents can be produced directly, allowing subsequent $\mathrm{CO}_{2}$ transportation and storage. No specific separation of oxygen in air or $\mathrm{CO}_{2}$ in flue gas is required, so significantly lower energy penalties can be expected. As a result, CLC is considered as a potential break through technology capable of meeting the $\mathrm{CO}_{2}$ capture and storage challenges.

The CLC concept actually emerged in the nineties, from pioneering studies conducted by Professor Ishida in Japan. Since then, over the last decade, numerous studies have been dedicated to validating concept and evaluating potential industrial applications such as fuel combustion. An increasing number of research programs have been dedicated to CLC all over the world, sponsored by governments, public institutions and companies, with Europe well ahead. Nowadays, CLC is no longer a dream, it is proven concept, with a large number of pilot plants operating at small scale. The process will develop during the next decade, during which the proven concept must to be converted into a viable industrial solution. Step by step, many of the remaining challenges, in terms of materials, process and technology, will be solved in order to address the perspective of $\mathrm{CO}_{2}$ capture and storage with a new clean and efficient solution.

IFP Energies nouvelles has been involved in CLC for many years through French and European programs and is now actively working on development of the technology jointly with Total. When we visited the leading universities in this field in Europe, at Chalmers, Zaragoza and Vienna 3 years ago, we became aware, with Professors Lyngfelt, Adanez and Hofbauer, of the need to gather the emerging CLC community in order to share research advances, potential applications and R\&D needs and challenges. We therefore proposed to host the 1st International Conference on CLC, as part of the IFP Energies nouvelles Scientific Symposia, the "Rencontres Scientifiques d'IFP Energies nouvelles". These symposia have the well recognized ability to gather players from the worlds of academic research, applied research and industry on emerging promising topics such as CLC.

The Conference was held on 17-19 March 2010 at IFP Energies nouvelles in Lyon, France, with sponsorship from Total, Alstom, Vattenfall and CPFD Software. 155 representatives from all over the world were present, with about $50 \%$ from research institutions and industrial organisations, to discuss:

- materials which can be used in chemical looping: development of synthetic materials, reactivity, oxygen transfer capacities, lifetime and deactivation of materials, attrition, etc.

- the technology and modelling of chemical looping reactors: reactor development, transportation of oxygen carrier particles, testing facilities, type of gas, liquid and solid feedstocks, reaction modelling and process modelling, etc.

- on chemical looping applications and the problem of upscaling: potential applications, upscaling, feasibility studies, as well as technical and economic evaluations, etc.

During the 3 days, 4 plenary lectures, 33 oral presentations and 30 posters were presented and can be downloaded from IFP Energies nouvelles website at:

$\mathrm{http} / / / \mathrm{www}$.ifpenergiesnouvelles.com/actualites/evenements/congres-et-conferences/organisespar-ifp-energies-nouvelles/rs-chemical-looping

This Oil \& Gas Science and Technology Special Issue on CLC includes 14 scientific publications derived from communications presented at the Conference. Together, these papers form an extensive review of the state of the art in CLC research and present some of the key issues for 
future CLC development that were discussed during the conference, such as the use and performance of synthetic materials and natural ores, redox mechanisms of the materials, mechanical stability and attrition, combustion reaction mechanisms depending on the feeds and materials, pilot plant design, circulation of materials, reactor modelling and use of CFD for CLC applications.

During the Round Table concluding the conference, it was clearly stated that the future of CLC will depend on our ability to manage and optimise materials, process and technologies at increasing scales, in order to make CLC technology available to the energy industry as soon as possible, in a 10-20 year time frame. In order to succeed, a lot of research remains to be conducted in the field of materials and control of reactions but also as regards optimisation in reactor design and in process modelling in order to minimise upscaling uncertainties. Numerous interactions will therefore be required between researchers from different fields but also between researchers, institutions and companies. Consequently, regular open meetings dedicated to CLC are vital. The first conference held in Lyon was a first successful step, and it was therefore decided to organise a second conference within 2 years. This 2nd International Conference on CLC will be hosted by the University of Darmstadt, Germany and organised by Professor J. Strohle. This will provide the opportunity to keep up to date with the rapid evolutions in the field of chemical looping.

Thierry Gauthier

Scientific Correspondent of the CLC Conference

IFP Energies nouvelles Expert 